\title{
Pengaruh Model Kooperatif Tipe Jigsaw terhadap Hasil Belajar Sejarah Siswa Kelas X di SMA Negeri 1 Manggelewa Tahun Pelajaran 2017/2018
}

\author{
Samsinah $^{1}$, Rosdiana ${ }^{2}$, Tati Haryati ${ }^{3}$ \\ STKIP Taman Siswa Bima \\ ${ }^{2}$ rosediana8885@gmail.com
}

\begin{abstract}
ABSTRAK
Tujuan penelitian ini adalah untuk mengatahui ada tidaknya pengaruh model kooperatif tipe jigsaw terhadap hasil belajar sejarah siswa kelas X di SMAN 1 Manggelewa Tahun Pelajaran 2017/2018. Jenis penelitian ini merupakan penelitian kuantitatif dengan metode quasi eksperimen. Desain adalah Pretest Posttes Control Group Design. Populasi penelitian adalah seluruh siswa kelas X di SMAN 1 Manggelewa Tahun Pelajaran 2017/2018, berjumlah 6 kelas yaitu X IPA ${ }^{1}$, X IPA ${ }^{2}$, X IPA ${ }^{3}$, X IPS ${ }^{1}$, X IPS 2 , dan X IPS 3 sebanyak 213 siswa. Teknik pengambilan sampel menggunakan Cluster Random Sampling, kelas eksperimen dalam penelitian ini adalah X IPS ${ }^{1}$ dan kelas kontrol adalah X IPS ${ }^{2}$. Teknik pengumpulan data dengan menggunakan teknik tes dan Teknik anlisis data menggunakan rumus uji-t. Hasil penelitian menunjukkan bahwa terdapat pengaruh signifikan dari penggunaan model kooperatif tipe jigsaw terhadap hasil belajar sejarah pada siswa kelas X di SMA Negeri 1 Manggelewa Tahun Pelajaran 2017/2018. Hal ini terbukti dengan hasil nilai rata-rata post-tes kelompok eksperimen 80,57 sedangkan rata-rata untuk kelompok kontrol 65,90 dan perhitungan dengan ujit diperoleh $t_{\text {hitung }}=27,389>t_{\text {tabel }}=4,001$, maka Ha diterima dan Ho ditolak.
\end{abstract}

Kata kunci: Model Kooperatif Tipe Jigsaw, Hasil Belajar Sejarah

\section{PENDAHULUAN}

Dalam Undang-Undang Nomor 20 Tahun 2003 tentang Sistem Pendidikan Nasional, menyatakan bahwa pendidikan nasional berfungsi mengembangkan kemampuan dan membentuk watak serta peradaban bangsa yang bermartabat dalam rangka mencerdaskan kehidupan bangsa. Tujuan pendidikan nasional adalah mengembangkan potensi peserta didik agar menjadi manusia yang beriman dan bertakwa kepada tuhan yang maha esa, berahlak mulia, sehat, berilmu, cakap, kreatif, mandiri dan menjadi warga negara yang demokratis serta bertanggung jawab.

Sekolah merupakan salah satu sasaran penyaluran pendidikan secara formal dan sejarah salah satu mata pelajaran yang diajarkan di sekolah yang bersifat formal. Guru sejarah harus mampu memahami karakteristik materi, peserta didik, dan metodologi pembelajaran dalam proses pembelajaran, terutama berkaitan dengan pemilihan model-model pembelajaran modern yang variatif dan inovatif. Selain itu, guru sejarah juga harus kreatif dalam merencanakan pembelajaran agar siswa menjadi aktif dan kreatif yang berdampak pada pemahaman siswa terhadap materi yang dipelajarinya.

Mata pelajaran sejarah selama ini sering diidentikkan sebagai mata pelajaran yang sifatnya hafalan dengan menghafal nama-nama tokoh, tahun, dan urutan peristiwa yang harus diingat kemudian diungkapkan kembali saat memjawab soal-soal ujian, sehingga siswa kurang tertarik untuk memahami dan menguasai konsep-konsep dasar pada materi sejarah. Selain itu, pembelajaran sejarah yang selama ini terjadi di sekolah-sekolah dirasakan kering dan tidak bermakna (Anggara, 2007:101).

Pengajaran sejarah disekolah memunculkan kesan tidak menarik, bahkan cenderung membosankan karena guru masih menggunakan metode konvensional (metode ceramah, tanya jawab dan pemberian tugas). Hal ini menyebabkan siswa tidak aktif dalam proses pembelajaran. Model konvensional kurang memfasilitasi kerjasama tim antar siswa satu dengan yang lain, sehingga siswa cenderung 
individual di dalam pembelajaran dan kurang mempersiapkan materi pembelajaran.

Prestasi yang dicapai oleh siswa setelah mengikuti kegiatan pembelajaran sejarah pada umumnya dijadikan tolak ukur keberhasilan pembelajaran sejarah. Sampai saat ini kondisi pengajaran sejarah memang belum seperti yang diharapkan. Hal ini ditandai dengan rendahnya prestasi belajar siswa (Rosdiana, dkk, 2017:49). Rendahnyanya prestasi belajar siswa dalam pembelajaran sejarah tidak terlepas dari beberapa faktor yaitu faktor intern dan faktor ekstern. Faktor intern meliputi intelegensi, minat, bakat, dan motivasi serta keadaan jasmani dan rohani. Sedangkan faktor ekstern meliputi model pembelajaran (Ahmadi dan Supriyono, 2013:138).

Berdasarkan hasil observasi awal yang dilakukan peneliti pada tanggal 13 November 2017 di kelas X SMAN 1 Manggelewa Tahun Pelajaran 2017/2018, menunjukkan bahwa hasil belajar siswa masih rendah yaitu nilainya cenderung dibawah kriteria ketuntasan minimal (KKM) yang ditetapkan oleh sekolah. Rata-rata nilai mid semester yang diperoleh siswa 70, sedangkan target KKM 75. Oleh karena itu, hasil belajar siswa kelas XI dalam mata pelajaran sejarah belum maksimal.

Berdasarkan hasil wawancara dengan guru mata pelajaran sejarah terdapat masalah lain selain hasil belajar yang tidak mencapai KKM yaitu kurangnya minat dan motivasi belajar siswa dalam mengikuti pelajaran. Hal ini dilihat ketika siswa mengikuti pelajaran sejarah, sedikit sekali siswa yang bersemangat untuk mengikuti pelajaran tersebut, karena cara belajar siswa yang masih terbiasa menerima ilmu pengatahuan dari guru saja. Ketika di berikan tugas untuk mencari materi, rata-rata siswa tidak mengerjakan tugas tersebut.

Berkaitan dengan permasalahan di atas, perlu diupayakan suatu bentuk pembelajaran yang mampu mengaktifkan siswa dengan penyajian materi sejarah yang lebih menarik agar dapat membantu siswa mengatasi kesulitan belajar dan menghilangkan persepsi buruk siswa terhadap pelajaran sejarah. Salah satu usaha untuk mengatasi permasalahan tersebut adalah menggunakan model pembelajaran kooperatif tipe jigsaw.

Model pembelajaran kooperatif tipe jigsaw termasuk faktor yang mempengaruhi prestasi belajar yang berasal dari luar diri siswa, karena model kooperatif tipe jigsaw merupakan suatu model pembelajaran dimana siswa diharapkan dapat bekerja sama, berdiskusi dan berdebat dengan teman, menilai kemampuan pengatahuan dan mengisi kekurangan anggota kelompoknya. Model Pembelajaran kooperatif dengan cara siswa belajar dalam kelompok kecil yang terdiri dari 4-6 orang siswa secara heterogen, memberikan kesempatan siswa dapat bekerja sama, saling ketergantungan positif diantara siswa yang satu dan siswa yang lain dan mampu bertanggung jawab secara mandiri Lie (dalam Rusman, 2013:218).

Menurut Slavin (2010:26), menyatakan pembelajaran kooperatif adalah pembelajaran teman sebaya dimana peserta didik bekerja dalam kelompok kecil yang memiliki latar belakang kemampuan yang berbeda. Jigsaw adalah adanya kerjasama dalam tim, siswa yang pandai dapat membantu pemahaman materi pelajaran kepada siswa yang kurang pandai. Tanggung jawab pembelajaran tidak hanya untuk diri siswa sendiri melainkan untuk siswa yang lain. Model pembelajaran kooperatif tipe jigsaw terdapat 2 jenis kelompok yaitu kelompok asal dan kelompok ahli. Dimana para siswa dalam kelompok ahli bertanggung jawab mengajarkan kepada kelompok asal. Dengan model pembelajaran kooperatif tipe jigsaw pemikiran tidak berasal dari satu kelompok saja dengan kata lain subyek yang berpikir lebih banyak. Jadi pada teknik jigsaw ini siswa dalam satu kelompok berpencar untuk berkumpul dengan anggota kelompok lain yang memiliki materi pembahasan yang sama.

Penelitian ini bertujuan untuk mengetahui Ada tidaknya pengaruh model kooperatif tipe jigsaw terhadap hasil belajar sejarah siswa kelas X di SMAN 1 Manggelewa Tahun Pelajaran 2017/2018. Berdasarkan penjelasan di atas dapat dirumuskan hipotesis sebagai berikut: (1) Ha: Ada pengaruh model pembelajaran kooperatif tipe jigsaw terhadap hasil belajar sejarah siswa 
kelas X SMAN 1 Manggelewa tahun pelajaran 2017/2018. (2) Ho: Tidak ada pengaruh model pembelajaran kooperatif tipe jigsaw terhadap hasil belajar siswa sejarah kelas $\mathrm{X}$ SMA $\mathrm{N} 1$ Manggelewa tahun pelajaran 2017/2018.

\section{METODE PENELITIAN}

Penelitian ini dilaksanakan di SMAN 1 Manggelewa Tahun Pelajaran 2017/2018. Waktu penelitian dilakukan pada semester Genap selama 3 bulan yaitu 15 Januari sampai 2 20 April 2018. Penelitian ini merupakan penelitian kuantitatif dengan metode quasi eksperimen. Rancangan analisis menggunakan Desain Penelitian Pretest Posttes Control Group Design. Desain tersebut dapat digambarkan sebagai berikut:

\begin{tabular}{cccc|}
\hline $\mathrm{E}$ & $\mathrm{O}_{1}$ & $\mathrm{X}$ & $\mathrm{O}_{2}$ \\
\cline { 2 - 4 } $\mathrm{K}$ & $\mathrm{O}_{3}$ & - & $\mathrm{O}_{4}$ \\
\hline
\end{tabular}

(Sugiyono, 2013:112).

Keterangan:

$$
\begin{aligned}
\mathrm{E}= & \text { Kelompok Eksperimen } \\
\mathrm{K}= & \text { Kelompok kontrol } \\
\mathrm{O}_{1}= & \text { Pretest siswa kelompok eksperimen } \\
\mathrm{O}_{2}= & \text { Posttes siswa kelompok eksperimen } \\
\mathrm{O}_{3}= & \text { Pretest siswa kelompok kontrol } \\
\mathrm{O}_{4}= & \text { Posttes siswa kelompok kontrol } \\
\mathrm{X}= & \text { Pembelajaran menggunakan model } \\
& \text { kooperatif tipe jigsaw }
\end{aligned}
$$

Populasi dalam penelitian ini adalah seluruh siswa kelas X SMAN 1 Manggelewa tahun pelajaran 2017/2018. Populasi terdiri dari 6 kelas dapat dilihat pada tabel sebagai berikut: Tabel 1. Jumlah Siswa Kelas X SMAN 1 Manggelewa

\begin{tabular}{clc}
\hline No & Kelas & Jumlah Siswa \\
\hline 1 & X IPA $^{1}$ & 36 Siswa \\
\hline 2 & X IPA $^{2}$ & 36 Siswa \\
\hline 3 & X IPA $^{3}$ & 36 Siswa \\
\hline 4 & X IPS $^{1}$ & 35 Siswa \\
\hline 5 & X IPS $^{2}$ & 35 Siswa \\
\hline 6 & X IPS $^{3}$ & 35 Siswa \\
\hline & Jumlah & 213 siswa \\
\hline
\end{tabular}

Pengambilan sampel dilakukan dengan teknik cluster random sampling. Sampel penelitian ini berjumlah 70 siswa, dengan rincian 35 siswa kelas eksperimen, dan 35 siswa kelas kontrol Konvensional di SMAN 1 Manggelewa. Variabel dalam penelitian ini ada dua, yaitu variabel terikat dan variabel bebas. Variabel terikatnya adalah Hasil belajar sejarah dan variabel bebasnya adalah model kooperatif tipe jigsaw untuk kelas eksperimen dan model Konvensional untuk kelas kontrol. Teknik pengumpulan data dalam penelitian ini berupa teknik tes untuk mengukur hasil belajar sejarah.

Instrumen penelitian yang digunakan dalam penelitian ini adalah tes. Tes yang berikan adalah tes objektif bentuk pilihan ganda yang digunakan untuk mengukur hasil belajar siswa mata pelajaran sejarah yang mengikuti pembelajaran dengan model pembelajaran kooperatif tipe jigsaw untuk kelas eksperimen dan model pembelajaran konvensional untuk kelas kontrol. Bentuk tes objektif dengan empat alternatif jawaban, setiap jawaban benar mendapat skor 1 sedangkan setiap jawaban salah mendapat skor 0 . Nilai akhir tes diperoleh dengan cara sebagai berikut:

Nilai $=\frac{\text { Jumlah benar }}{\text { Jumlah soal }} \times 100$

Adapun teknik analisis data yang digunakan untuk menguji hipotesis dalam penelitian ini adalah menggunakan perhitungan statistik $U_{j i}$ beda rata-rata (Uji $\mathrm{t})$.

\section{HASIL PENELITIAN DAN PEMBAHASAN Data Kemampuan Awal Sejarah}

Pengambilan data kemampuan awal pada penelitian ini menggunakan data nilai pretest yang diberikan kepada kelas eksperimen dan kelas kontrol, kemudian data ini diuji normalitas, homogenitas dan uji keseimbangan.

\section{Uji Normalitas}

Uji Normalitas digunakan untuk menguji data yang diperoleh berdistribusi normal. Uji normalitas kemampuan awal menggunakan one sample kolmogorov smirnov, uji normalitas pre-test kelas eksperimen dan kontrol dapat dilihat pada tabel sebagai berikut:

Tabel 2. Rangkuman Hasil Uji Normalitas (Pretest)

\begin{tabular}{|l|l|c|c|c|}
\hline No & \multicolumn{1}{|c|}{ Variabel } & $\begin{array}{c}\text { Asymp } \\
\text { Sig (2- } \\
\text { tailed) }\end{array}$ & $\begin{array}{c}\text { Signifik } \\
\text { ansi }\end{array}$ & $\begin{array}{c}\text { Keputu } \\
\text { San }\end{array}$ \\
\hline 1. & $\begin{array}{l}\text { Kelas } \\
\text { eksperimen }\end{array}$ &, 083 & 0,05 & Diterima \\
\hline 2. & Kelas kontrol &, 068 & 0,05 & Diterima \\
\hline
\end{tabular}


Berdasarkan tabel di atas, dapat dilihat bahwa nilai signifikasin lebih besar dari 0,05, maka normalitas nilai pre-test kelas eksperimen dan kontrol diterima. Dapat disimpulkan bahwa nilai pre-test kelas eksperimen dan kontrol berasal dari populasi normal.

\section{Uji Homogenitas}

Uji homogen dilakukan untuk mengatahui apakah kedua sampel yang diambil dalam penelitian ini berasal dari populasi yang homogen atau tidak. Uji pada penelitian ini menggunakan uji Levene' test. Hasil uji homogen dapat dilihat pada tabel sebagai berikut:

Tabel 3. Rangkuman Hasil Homogenitas (Pre-test)

\begin{tabular}{lllll}
\hline Analisis & $\mathrm{F}_{\text {hitung }}$ & $\mathrm{F}_{\text {tabel }}$ & Keputusan & Ket \\
\hline
\end{tabular}
\begin{tabular}{lllll}
\hline Varians $(\mathrm{F})$ & 0,968 & 4,001 & Ha diterima & Homogen \\
\hline
\end{tabular}

Berdasarkan tabel di atas, nilai signifikansi hasil pengujian nilai pre-test kelas eksperimen dan kontrol dengan nilai $F_{\text {hitung }}=0,968$ selanjutnya di konsultasikan dengan $\mathrm{F}_{\text {tabel }}$ dan $\mathrm{dk}$ penyebut 68-1. Taraf signifikansinya 0,05 . Diperoleh $F_{\text {tabe }}=$ 4,001 , jadi $F_{\text {hitung }}=0,968<\mathrm{F}_{\text {tabel }}=4,001$. Dapat disimpulkan bahwa nilai pre-test kelas eksperimen dan kontrol berasal dari populasi yang homogen. Uji keseimbangan

Uji keseimbangan dilakukan terhadap nilai pretest kelas eksperimen dan kelas kontrol. Berikut hasil uji keseimbangan dapat dilihat pada tabel sebagai berikut:

Tabel 4. Hasil Uji Keseimbangan dengan t-test

\begin{tabular}{|c|c|c|c|}
\hline Kelas & $\begin{array}{c}\text { Asymp.Sig } \\
\text { (2-tailed) }\end{array}$ & $\begin{array}{c}\text { Signifi } \\
\text { kansi }\end{array}$ & Keputasan \\
\hline $\begin{array}{c}\text { Eksperimen } \\
\text { dan kontrol }\end{array}$ & 0,454 & 0,05 & $\begin{array}{c}\text { Ho } \\
\text { diterima }\end{array}$ \\
\hline
\end{tabular}

Berdasarkan tabel di atas, nilai signifikansi hasil uji keseimbangan kelas eksperimen dan kelas kontrol dengan nilai 0,454>0,05, maka Ho diterima. Sehingga dapat disimpullkan kedua kelas populasi memiliki kemampuan awal yang sama atau seimbang.

\section{Uji Prasayarat untuk Pengujian Hipotesis}

Sebelum data dianalisis menggunaakan Uji dengan t-test, terlebih dahulu data harus memenuhi uji normalitas dan uji homogenitas Levene' test..

\section{Uji Normalitas Hasil Belajar ( post-test)}

Hasil uji normalitas post-test kelas eksperimen dan kontrol dapat dilihat pada tabel sebagai berikut:

Tabel 5. Hasil Uji Normalitas (Post-test)

\begin{tabular}{|c|c|c|c|}
\hline Variabel & $\begin{array}{c}\text { Asymp.Sig } \\
\text { (2-tailed) }\end{array}$ & $\begin{array}{c}\text { Signifik } \\
\text { ansi }\end{array}$ & $\begin{array}{c}\text { Kepu } \\
\text { tusan }\end{array}$ \\
\hline $\begin{array}{c}\text { Kelas } \\
\text { eksperimen }\end{array}$ &, 200 & 0,05 & Diterima \\
\hline $\begin{array}{c}\text { Post-test kelas } \\
\text { kontrol }\end{array}$ &, 143 & 0,05 & Diterima \\
\hline
\end{tabular}

Berdasarkan hasil uji normalitas post-test kelas eksperimen dan kontrol di atas dapat disimpulkan bahwa data hasil belajar kelas eksperimen dan kontrol berdistribusi normal.

Uji Homogenitas Hasil Belajar (post-test)

Uji homogenitas pada penelitian ini menggunakan uji levene's test. Hasil uji homogenitas hasil belajar dapat dilihat pada tabel sebagai berikut:

Tabel 6. Rangkuman Hasil Homogenitas (post-test)

\begin{tabular}{lcccc}
\hline Analisis & $\mathrm{F}_{\text {hitung }}$ & $\mathrm{F}_{\text {tabel }}$ & Keputusan & Ket \\
\hline $\begin{array}{l}\text { Varians } \\
\text { (F) }\end{array}$ & 0,374 & 4,001 & $\begin{array}{c}\text { Ho } \\
\text { diterima }\end{array}$ & Homogen \\
\end{tabular}

Berdasarkan uji homogenitas di atas, maka dapat dilihat $F_{\text {hitung }}$ lebih kecil dari $F_{\text {tabel, }}$ jadi $F_{\text {hitung }}=0,374<F_{\text {tabel }}=4,001$. Maka dapat disimpulkan bahwa kedua kelas berasal populasi yang homogen.

\section{Uji Hipotesis (post-test)}

Uji hipotesis dilakukan pada nilai pot-test kelas eksperimen dan kontrol dapat dilihat pada tabel sebagai berikut:

Tabel 6.Hasil Uji Hipotesis

\begin{tabular}{|c|c|c|c|}
\hline Kelas & $\mathrm{F}_{\text {hitung }}$ & $\mathrm{F}_{\text {tabel }}$ & $\begin{array}{c}\text { Kesimpulan } \\
\text { pada } \alpha=0,05\end{array}$ \\
\hline $\begin{array}{c}\text { Kelas } \\
\text { eksperimen } \\
\text { dan kontrol }\end{array}$ & 27,389 & 4,001 & Ha Diterima \\
\hline
\end{tabular}

Berdasarka hasil penelitian, $F_{\text {hitung }}$ adalah 27,389 dan $F_{\text {tabel }}$ adalah 4,001. Dengan demikian $\mathrm{F}_{\text {hitung }}$ lebih besar dari $\mathrm{F}_{\text {tabel }} . \mathrm{F}_{\text {hitung }} 27,389>\mathrm{F}_{\text {tabel }}$ 4,001, maka dapat disimpulkan bahwa ada pengaruh penggunaan model pembelajaran kooperatif tipe jigsaw terhadap hasil belajar sejarah. 


\section{PEMBAHASAN}

Penelitian ini bertujuan untuk mengatahui perbedaan pengaruh antara hasil belajar sejarah yang menerapkan penggunaan model pembelajaran kooperatif tipe Jigsaw dan model pembelajaran konvensional.

Dari hasil uji validitas soal diperoleh 15 item yang valid sehingga dapat dipergunakan dalam penelitian. Tahap selanjutnya uji reliabilitas diperoleh 0,835>0,7. Berdasarkan uji reliabilitas dapat diketahui instrumen penelitian reliabel digunakan dalam penelitian. Untuk mengetahui kemampuan awal dari kelas eksperimen dan kelas kontrol, peneliti mengambil nilai pre-test, rata-rata nilai pre-test yang diperoleh dari kelas eksperimen sebesar 69,33 sedangkan dari kelas kontrol sebesar 67,62. Kemudian dilakukan uji persyaratan analisis nilai pre_test yaitu uji normalitas kelas eksperimen diperoleh Asymp.Sig (2 detailed) 0,83>0.05 dinyatakan berdistribusi normal dan nilai pre_test kelas kontrol diperoleh Asymp.Sig (2 detailed) 0,068>0,05 dinyatakan berdistribusi normal. Uji homogenitas $F_{\text {hitung }}$ lebih kecil dari $\mathrm{F}_{\text {tabel }}$, diperoleh $\mathrm{F}_{\text {hitung }} 0,968<\mathrm{F}_{\text {tabel }}$ 4,001. Berdasarkan dari nilai pre_test kelas eksperimen dan kontrol dinyatakan berasal dari populasi yang homogen. Kemudian dilakukan uji keseimbangan diperoleh Asymp.Sig (2 detailed) 0,454>0,05. Maka dari hasil uji keseimbangan tersebut menunjukan bahwa tidak ada perbedaan yang signifikan nilai pre-test sejarah kelas eksperimen dan kelas kontrol.

Berdasarkan hasil penelitian diperoleh nilai rata-rata post-test siswa pada kelas eksperimen sebesar 80,57 sedangkan dari kelas kontrol sebesar 65,90. Hal ini menunjukan bahwa penguasaan konsep sejarah materi teori tentang proses masuk dan berkembanganya agama dan kebudayaan Hindu-Budha di Indonesia yang diberi perlakuan dengan model pembelajaran kooperatif jigsaw lebih baik dari pada yang diberi perlakuan dengan model pembelajaran konvensional. Setelah menerapkan model pembelajaran kooperatif tipe jigsaw pada kelas eksperimen dan model konvensional pada kelas kontrol. Dari hasil kelas eksperimen, terdapat pengaruh positif dan signifikan penerapan model pembelajaran kooperatif tipe jigsaw.

Berdasarkan hasil uji hipotesis yaitu uji normalitas kelas eksperimen diperoleh Asymp.Sig(2 detailed) 0,200>0,05 dinyatakan berdistribusi normal sedangan kelas kontrol diperoleh Asymp.Sig(2 detailed) 0,143> 0,05 dinyatakan normal. Uji homogenitas kelas eksperimen dan kelas kontrol post_test diperoleh $F_{\text {hitung }} 0,374<F_{\text {tabel }} 4,001$ dinyatakan bahwa kedua populasi homogen. Berdasarkan hasil uji t diperoleh $t_{\text {hitung }}=27,389>t_{\text {tabel }}=4,001$ yang artinya Ha diterima dan Ho ditolak yang berarti terdapat pengaruh yang signifikan penggunaan model pembelajaraan kooperatif tipe jigsaw terhadap hasil belajar sejarah siswa kelas $\mathrm{X}$ di SMA Negeri 1 Manggelewa tahun pelajaran2017/2018.

Model pembelajaran kooperatif tipe jigsaw dapat berpengaruh terhadap hasil belajar sejarah, karena model pembembelajaran ini merupakan pembelajaran yang berpusat pada siswa (student center), dimana siswa berdiskusi dan berdebat dengan teman untuk memecahkan masalah materi pembelajaran. Metode pembelajaran ini mengutamakan kerjasama antar siswa dalam kelompok untuk mencapai tujuan pembelajaran. Anggota dari kelompok yang berbeda dengan topik yang sama (ahli) bertemu untuk berdiskusi antar ahli agar dapat membantu satu sama lain dengan topik yang ditugaskan. Setelah selesai diskusi kemudian kembali ke kelompok asal untuk menjelaskan materi kepada anggota kelompok terkait yang telah dibahas dalam kelompok ahli. Jigsaw didesain agar siswa mempunyai tanggung jawab secara mandiri dan supaya saling ketergantungan positif terhadap teman sekelompoknya.

Penerapan Model pembelajaran kooperatif tipe jigsaw memiliki beberapa keunggulan, diantaranya: (1) peserta didik dapat mengembangkan kreativitas, kemampuan, dan daya pemecahan masalah menurut kehendaknya sendiri, (2) hubungan antara guru dan peserta didik berjalan secara seimbang dan suasana belajar menjadi sangat akrab sehingga harmonis, (3) memotivasi guru untuk bekerja lebih aktif dan kreatif. (4) mampu memadukan berbagai 
pendekatan belajar, yaitu pendekatan kelas, kelompok, dan individual.

Hasil penelitian ini sejalan dengan penelitian Yenni Agustine Shovia Insany (2016) dengan judul "Pengaruh Model Pembelajaran Kooperatif Tipe Jigsaw terhadap Prestasi Belajar Siswa Pada Pelajaran Siswa SMK". Menyatakan bahwa ada pengaruh yang signifikan dari model pembelajaran Kooperatif Tipe Jigsaw terhadap prestasi belajar pada pelajaran Fisika Kelas XI SMK/Sederatai di Pamekasan Tahun Ajaran 2015/2016.

\section{KESIMPULAN}

Berdasarkan hasil analisis data dan pembahasan hasil penelitian, maka dapat disimpulkan bahwa ada pengaruh yang signifikan penggunaan model pembelajaran kooperatif tipe jigsaw terhadap hasil belajar sejarah siswa kelas X di SMAN 1 Manggelewa Tahun Pelajaran 2017/2018. Hal ini dapat dibuktikan dengan nilai rata-rata hasil belajar kelas eksperimen yang menerapkan penggunaan model pembelajaran kooperatif tipe jigsaw sebesar 80,57 sedangkan rata-rata nilai hasil belajar kelas kontrol yang menerapkan penggunaan model konvensional sebesar 65,90. Dengan demikian, dapat disimpulkan bahwa hasil belajar yang menerapkan penggunaan model pembelajaran kooperatif tipe jigsaw lebih baik dibandingkan dengan hasil belajar yang menerapkan penggunaan model konvensional.

\section{DAFTAR PUSTAKA}

Ahmadi, H. Abu \& Supriyono, Widodo. (2013). Psikologi Belajar. Jakarta: Rineka Cipta.

Anggara, Boyi. (2007). Pembelajaran Sejarah yang Berorientasi Pada Masalah-Masalah sosial kontemporer. Makalah: Universitas Negeri Semarang.

Rosdiana, Djono \& Arif Musadad. (2017). Pengaruh Penggunaan Model Pembelajarah Problem Based Learning, Inquiri, dan Konvesional terhadao Prestasi Belajar Sejarah Ditinjau Dari Minat Belajar Siswa (Studi Eksoerimental Kelas XI SMA Negeri Se-Kabupaten Bima Tahun Pelajaran
2015/2016). Historika Jurnal Penelitian Pendidikan Sejarah, 20(01), 49.

Rusman. (2013). Model-Model Pembelajaran: Mengembangkan Profesionalisme Guru (edisi ke 2). Jakarta: RajaGrafindo Persada.

Slavin, Robert E. (2010). Cooverative Learning (Teori, Riset, Praktik). Bandung: Nusa Media. Sugiyono. 2013. Metode Penelitian Kuantitatif, Kualitatif dan REDD. Bandung: Alfbeta. 